\section{Hydrogen Cyanamide Induces Budbreak of Peaches and Nectarines Following Inadequate Chilling}

\author{
W.A. Dozier, Jr., A.A. Powell, and A.W. Caylor \\ Horticulture Department and Alabama Agricultural Experiment Station, \\ Auburn University, AL 36849

\section{N.R. McDaniel, E.L. Carden, and J.A. McGuire \\ Alabama Agricultural Experiment Station, Auburn University, AL 36849}

Additional index words. Prunus persica, rest, chilling requirement, dormancy, Dormex

Abstract. Hydrogen cyanamide (Dormex) treatments were applied to 17 insufficiently chilled peach and nectarine cultivars $\approx 6$ weeks after normal budbreak. Treatment effectively induced vegetative budbreak and reduced shoot dieback. The responses to Dormex treatments were linear, with the $2 \%$ rate being more effective than the 0 and $1 \%$ rates in most cases.

Dormant deciduous fruit trees have a chilling requirement that is satisfied by exposure to low temperature (Samish, 1954). Chemical inducement of budbreak of insufficiently chilled deciduous fruit trees is practiced in some areas of the world (Diaz et al., 1987; Erez, 1987; Erez and Lavi, 1985). Materials that have been used to induce budbreak of insufficiently chilled buds include: hydrogen cyanamide, thiourea, potassium nitrate, oil plus dinitrophenols, gibberellins, and cytokinins (Diaz et al., 1987; Erez, 1987; Erez and Lavi, 1985; Erez et al., 1971; Shulman et al., 1986). These chemicals have been more effective when used in combination with proper timing of cultural practices, such as defoliation, water stress, and pruning (Diaz et al., 1987; Erez and Lavi, 1985), and effectiveness depends on rate and time of application (Erez, 1987; Erez et al., 1971; Shulman et al., 1986). The response of individual buds to treatment depends on the stage of bud development (Erez et al., 1971).

Hydrogen cyanamide has been reported to be a useful dormancy-breaking agent for peaches (Diaz et al., 1987; Shulman et al., 1986). Shulman et al. (1986) reported that when hydrogen cyanamide was applied several weeks before natural budbreak in peach, the most consistent and complete bloom development was seen.

In the southeastern United States, peach cultivars are adversely affected, in some years, by insufficient chilling and/or higher than normal winter temperatures (Erez et al.,

Received for publication 30 Mar. 1990. Alabama Agricultural Experiment Station Journal Series no. $11-902475 \mathrm{P}$. The cost of publishing this paper was defrayed in part by the payment of page charges. Under postal regulations, this paper therefore must be hereby marked advertisement solely to indicate this fact. 1979b; Weinberger, 1967). High temperature during the chilling period can have a negative effect on the termination of rest and subsequent budbreak of peach (Erez et al., 1979a; Weinberger, 1954). The extent of chilling negation depends on the temperature and exposure time at a given temperature (Couvillon and Erez, 1985).

Of 55 peach and nectarine cultivars growing at the Gulf Coast Substation, Fairhope, Ala., insufficient chilling was received during the 1988-89 dormant season to satisfy the chilling requirement of 17 of these cultivars. All cultivars with a chilling requirement $\leq 650 \mathrm{hr}$ bloomed and foliated during or before March. except for 'La White', which has a reported 650 -hr chilling requirement. Some cultivars with reported chilling requirements of $750 \mathrm{hr}$, such as 'Sunbrite', 'Brighton', and 'Sunland', foliated and bloomed normally.

Trees set in Mar. 1985 foliated and fruited normally in previous seasons. Not only was insufficient chilling for certain cultivars received during the 1988-89 dormant season (Table 1), but temperatures were higher during dormancy than in previous years (Table 2 ). This mild weather could have had a greater negation effect on chilling during 1988-89 than in previous seasons (Couvillon and Erez, 1985; Erez et al., 1979a, 1979b). By 13 Apr., floral bud abortion and varying degrees of terminal dieback were evident on the 17 insufficiently chilled cultivars.

This study was undertaken to determine if treatments with hydrogen cyanamide applied following normal budbreak would induce buds to break: All previously reported treatment applications of hydrogen cyanamide had been applied before normal budbreak.

Trees in the experimental planting were spaced $6.1 \times 7.6 \mathrm{~m}$. Recommended cultural practices for peaches and nectarines were followed. The trees were pruned by hand to an open center in late January. Bloom and foliation data were collected on each cultivar as they occurred. On 13 Apr., the 17 insufficiently chilled cultivars showed no sign of bud swell and were treated with hydrogen cyanamide (Dormex; SKW Trostberg AG, Trostberg, Federal Republic of Germany). Units of four trees from each cultivar were randomized within each of four blocks at the beginning of the experiment. Dormex at 0 , $\mathrm{I} \%$, or $2 \%$ plus $0.25 \% \mathrm{X}-77$ surfactant was applied to different sectors of each tree. This provided a set of cultivars as whole plots, with sectors of each tree treated as sub-plots in a split-plot design. Analyses of variance were computed for percent shoot mortality and percent budbreak as affected by Dormex. Orthogonal polynomials were computed to determine forms of the responses to levels of Dormex.

Treatments were applied to run-off with a hand-held spray gun. At time of application, the air was at $21 \mathrm{C}$ and a slight wind was blowing.

Six shoots, each $25 \mathrm{~cm}$ long, of the previous season's growth were randomly selected in the center of each treatment quadrant on 2 May (21 days after treatment application). The percent budbreak and the degree of shoot dieback was determined. Ten shoots that had not been pruned were randomly selected in each treatment quadrant to determine treatment effect on percent terminal budbreak and growth.

All cultivars that did not bloom and foliate have a reported chilling requirement of $\geq 750$ hr. except 'La White', which has a reported chilling requirement of $650 \mathrm{hr}$ (Table 3).

Dormex treatments had a linear affect on percent budbreak (Table 3). Mean budbreak was $15.9 \%$ for $0 \%$ Dormex and $70.7 \%$ for $2 \%$ Dormex. The response was quadratic on two peach and two nectarine cultivars because in three of the cases the response was higher and in one case it was lower than the average for $1 \%$ Dormex.

The mean percent shoot dieback was greater on the nontreated than on the Dormex-treated shoots (Table 4). Except for three peach and three nectarine cultivars, the response was

Table 1. Chilling hours received by peaches each season during the past 6 years at Fairhope, Ala.

\begin{tabular}{lccc}
\hline \hline & \multicolumn{3}{c}{$\begin{array}{c}\text { Hours chilling below } \\
\text { above } 0 C^{2}\end{array}$} \\
\cline { 2 - 4 } Ycar & 15 Fcb. & 1 Mar. & 15 Mar. \\
\hline $1988-89$ & 466 & 549 & 622 \\
$1987-88$ & 806 & 885 & 924 \\
$1986-87$ & 572 & 594 & 645 \\
$1985-86$ & 735 & 777 & $\ldots$ \\
$1984-85$ & 882 & 906 & 907 \\
$1983-84$ & 898 & 970 & 1066 \\
Mcan & 726 & 780 & 833 \\
\hline
\end{tabular}

${ }^{\mathrm{z}}$ Data obtained from Southeastern Agricultural Weather Service Center, National Weather Service, Auburn Univ., Ala. 
Table 2. Average temperatures $\left({ }^{\circ} \mathrm{C}\right)$ and departures from average (DFA) at Fairhope, Ala. ${ }^{\mathrm{z}}$

\begin{tabular}{|c|c|c|c|c|c|c|c|c|}
\hline \multirow{3}{*}{$\frac{\text { Ycar }}{1983}$} & \multicolumn{2}{|c|}{ December } & \multicolumn{2}{|c|}{ January } & \multicolumn{2}{|c|}{ February } & \multicolumn{2}{|c|}{ March } \\
\hline & \multicolumn{2}{|c|}{ Average DFA } & \multicolumn{2}{|c|}{ Avcrage DFA } & \multicolumn{2}{|c|}{ Average DFA } & \multicolumn{2}{|c|}{ Average DFA } \\
\hline & 9.4 & -2.50 & -- & $\cdots$ & $\cdots$ & $\ldots$ & $\ldots$ & $\ldots$ \\
\hline 1984 & 15.9 & +3.94 & 8.0 & -2.94 & 11.5 & -0.78 & 14.3 & -1.39 \\
\hline 1985 & 9.2 & -2.83 & 6.0 & -4.89 & 11.2 & -1.00 & 17.6 & +1.83 \\
\hline 1986 & 11.1 & -0.94 & 9.5 & -1.39 & 13.3 & +1.06 & 14.5 & -1.22 \\
\hline 1987 & 12.9 & +0.89 & 8.8 & -2.06 & 11.8 & -0.44 & 15.4 & -0.33 \\
\hline 1988 & 11.6 & -0.39 & 8.2 & -2.78 & 9.9 & -2.33 & 14.8 & -0.94 \\
\hline 1989 & -.. & $\ldots$ & 14.0 & +3.11 & 11.9 & -0.28 & 16.2 & +0.50 \\
\hline
\end{tabular}

${ }^{\mathrm{z}}$ Monthly average of the daily mean maximum and minimum and departures from average for month indicated. Data obtained from Southeastern Agricultural Weather Service Center, National Weather Service, Auburn Univ., Ala.

Table 3. Percent lateral budbreak on 17 cultivars of peaches and nectarines following insufficient chilling and Dormex treatments. 1989.

\begin{tabular}{|c|c|c|c|c|c|c|}
\hline \multirow[b]{2}{*}{ Cultivar } & \multirow{2}{*}{$\begin{array}{l}\text { Chilling } \\
\text { requirement } \\
\text { (hr) }\end{array}$} & \multicolumn{3}{|c|}{ Dormex concn } & \multicolumn{2}{|c|}{ Significance } \\
\hline & & $0 \%$ & $1 \%$ & $2 \%$ & Linear & Quadratic \\
\hline & \multicolumn{6}{|c|}{ Percent budbreak } \\
\hline Pasch & & & & & & \\
\hline BY78-289 & $?$ & 28.1 & 45.2 & 78.9 & $* *$ & NS \\
\hline Goldilocks & 750 & 0.0 & 10.3 & 36.0 & $\cdots$ & NS \\
\hline La Premicr & 1050 & 16.8 & 33.2 & 67.0 & $* *$ & NS \\
\hline La Whitc & 650 & 13.2 & 60.6 & 86.6 & 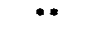 & NS \\
\hline Loring & 750 & 14.3 & 46.5 & 70.2 & $\because$ & vs \\
\hline Redskin & 750 & 17.5 & 69.8 & 72.9 & $\cdots$ & $\cdots$ \\
\hline Sun Prince & 300 & 18.6 & 66.3 & 77.1 & $* *$ & * \\
\hline Whitc Halc & 750 & 15.9 & 40.9 & 63.8 & 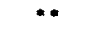 & NS \\
\hline Wild Rose & 750 & 9.6 & 28.7 & 49.0 & $*$ & NS \\
\hline Winblo & 850 & 10.5 & 30.4 & 66.2 & $*$ & NS \\
\hline \multicolumn{7}{|l|}{ Nectarine } \\
\hline Summer Beaury & 750 & 15.7 & 46.1 & 72.8 & 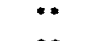 & NS \\
\hline Early Bird & 750 & 11.8 & 47.3 & 84.8 & $\bullet$ & NS \\
\hline Carolina Red & 750 & 25.2 & 68.0 & 79.6 & $\cdots$ & - \\
\hline Crimson Gold & 750 & 15.3 & 45.9 & 74.0 & $\cdots$ & NS \\
\hline Durbin & 850 & 7.0 & 24.6 & 56.8 & $*$ & NS \\
\hline Red Gold & 850 & 24.5 & 39.5 & 86.5 & $\cdots$ & • \\
\hline Sun Glo & 850 & 27.5 & 53.8 & 77.1 & $\bullet$ & • \\
\hline Mean & & 15.9 & 44.9 & 70.7 & $* *$ & NS \\
\hline
\end{tabular}

**** ${ }^{\mathrm{NS}}$ Significant at $P=0.05$ or 0.01 or not significant at $P>0.05$, respectively. Data shown are means of 24 observations.

Table 4. Percent shoot dieback on 17 cultivars of peaches and nectarines following insufficient chilling and Dormex treatments. 1989.

\begin{tabular}{|c|c|c|c|c|c|c|}
\hline \multirow[b]{2}{*}{ Cultivar } & \multirow{2}{*}{$\begin{array}{c}\begin{array}{c}\text { Chilling } \\
\text { requirement } \\
\text { (hr) }\end{array} \\
\end{array}$} & \multicolumn{3}{|c|}{ Dormex conen } & \multicolumn{2}{|c|}{ Significance } \\
\hline & & $0 \%$ & $1 \%$ & $2 \%$ & Linear & Quadratic \\
\hline \multicolumn{7}{|c|}{ Percent shoot dieback } \\
\hline Peach & & & & & & \\
\hline BY78-289 & (?) & 58.4 & 50.6 & 30.3 & * & NS \\
\hline Goldilocks & 750 & 79.4 & 94.2 & 37.8 & $*$ & $*$ \\
\hline La Premicr & 1050 & 34.0 & 35.5 & 8.7 & $\cdot$ & • \\
\hline La White & 650 & 26.5 & 9.2 & 2.6 & • & vS \\
\hline Loring & 750 & 10.3 & 1.7 & 0.6 & NS & NS \\
\hline Redskin & 750 & 25.5 & 3.2 & 2.5 & - & • \\
\hline Sun Prince & 800 & 16.6 & 8.8 & 4.7 & NS & NS \\
\hline White Hale & 750 & 10.3 & 8.1 & 1.2 & NS & NS \\
\hline Wild Rose & 750 & 38.8 & 16.7 & 3.5 & $* *$ & NS \\
\hline Winblo & 850 & 62.9 & 75.1 & 9.8 & $* *$ & $* *$ \\
\hline \multicolumn{7}{|l|}{ Nectarine } \\
\hline Summer Beauty & 750 & 22.5 & 8.5 & 15.0 & NS & NS \\
\hline Early Bird & 750 & 42.4 & 15.2 & 14.3 & $\cdot$ & NS \\
\hline Carolina Red & 750 & 37.9 & 14.2 & 17.8 & * & NS \\
\hline Crimson Gold & 750 & 44.0 & 33.4 & 13.2 & - & NS \\
\hline Durbin & 850 & 66.6 & 61.6 & 16.2 & $\cdots$ & $\cdot$ \\
\hline Red Gold & 850 & 20.2 & 16.7 & 8.3 & NS & NS \\
\hline Sun Glo & 850 & 9.0 & 0.5 & 2.4 & vs & NS \\
\hline Mean & & 35.2 & 26.3 & 10.9 & $\cdots$ & NS \\
\hline
\end{tabular}

${ }^{*},{ }^{*}{ }^{\mathrm{NS}}$ Significant at $P=0.05$ or 0.01 or not significant at $P>0.05$, respectively. Data shown arc means of 24 observations. linear and shoot dieback decreased with increasing Dormex rates. Percent shoot dieback in four peach and one nectarine cultivar responded quadratically to treatment. In these cases, shoot dieback with $1 \%$ Dormex was equal to or greater than that of the control.

Mean percent terminal budbreak following Dormex treatments was curvelinear (Table 5). i.e., it increased with increasing Dormex rates, with a similar response at $1 \%$ and $2 \%$. The response of terminal buds to Dormex was nonsignificant for four nectarine and one peach cultivar, but curvilinear for four peach and one nectarine cultivar due to an equal or greater response to $1 \%$ than $2 \%$ Dormex.

Scalabrelli and Couvillon (1986) reported terminal buds to have the shortest chilling requirement and to exhibit less differential response to various temperatures than the other bud types. Our data support this finding since a greater number of terminal than lateral buds broke on untreated shoots, as well as those treated with $1 \%$ Dormex. There was no difference between lateral and terminal budbreak with the 2\% Dormex rate. Hydrogen cyanamide was reported to induce early, uniform, and full budbreak in peach (Shulman et al., 1986). However, it was suggested by Erez (1987) that hydrogen cyanamide should not be applied to peaches <4 weeks before bud swell due to possible heavy damage to flower buds and young shoots from interaction between cool conditions and hydrogen cyanamide phytotoxicity. In this study, applications were made late in the spring after temperatures were above $20 \mathrm{C}$ and flower buds had aborted. This may explain why no phytotoxicity was observed.

Dormex treatments resulted in a higher level of lateral and terminal budbreak and less shoot dieback than that which occurred on the nontreated shoots; in most cases, $2 \%$ was more effective than $1 \%$. New growth arising from the Donnex-treated shoots was more vigorous than that from the nontreated shoots and no adverse effects appeared to be associated with the Donnex treatments. 'Goldilocks' was the only cultivar that exhibited major scaffold limb death. Many nontreated shoots of trees of all cultivars died. This dieback, coupled with reduced budbreak and vigor, likely will reduce next season's fruiting potential of the controls, but not of those treated with Dormex.

\section{Literature Cited}

Couvillon. G.A. and A. Erez. 1985. Effect of level and duration of high temperatures on rest in the peach. J. Amer. Soc. Hort. Sci. 110:579-581.

Diaz, D.H., A. Alvarez, and J. Sandoval. 1987. Cultural and chemical practices to induce uniform budbreak of peach and apple under warm climates in Mexico. Acta Hort. 199:129-136.

Erez, A. 1987. Chemical control of budbreak. HortScience 22:1240-1243.

Erez, A. and B. Lavi. 1985. Breaking bud rest of several deciduous fruit tree species in the Kenyan Highlands. Acta Hort. 158:239-248.

Erez, A., G.A. Couvillon. and C.H. Hendershott. 1979a. Quantitative chilling enhancement and negation in peach buds by high temperatures in 
Table 5. Percent terminal budbreak on 17 cultivars of peaches and nectarines following insufficient chilling and Dormex treatments. 1989.

\begin{tabular}{|c|c|c|c|c|c|c|}
\hline \multirow[b]{2}{*}{ Cultivar } & \multirow{2}{*}{$\begin{array}{c}\text { Chilling } \\
\text { requirement } \\
(\mathrm{hr})\end{array}$} & \multicolumn{3}{|c|}{ Dormex concn } & \multicolumn{2}{|c|}{ Significance } \\
\hline & & $0 \%$ & $1 \%$ & $2 \%$ & Linear & Quadratic \\
\hline \multicolumn{7}{|c|}{ Percent terminal budbreak } \\
\hline Peach & & & & & & \\
\hline BY78-289 & $(?)$ & 17.8 & 83.3 & 44.4 & - & $*$ \\
\hline Goldilocks & 750 & 4.2 & 16.7 & 25.0 & NS & NS \\
\hline La Premier & 1050 & 27.8 & 77.8 & 88.9 & $*$ & NS \\
\hline La White & 650 & 50.0 & 75.0 & 75.0 & - & NS \\
\hline Loring & 750 & 37.5 & 87.5 & 87.5 & $\cdots$ & - \\
\hline Redskin & 750 & 66.7 & 91.7 & 91.7 & • & NS \\
\hline Sun Prince & 800 & 29.2 & 75.0 & 62.5 & $*$ & $*$ \\
\hline Whitc Halc & 750 & 45.8 & 79.2 & 87.5 & 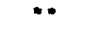 & NS \\
\hline Wild Rose & 750 & 28.9 & 94.4 & 100.0 & $\cdots$ & * \\
\hline Winblo & 850 & 8.3 & 41.7 & 66.7 & $*$ & NS \\
\hline \multicolumn{7}{|l|}{ Nectarine } \\
\hline Summer Beauty & 750 & 50.0 & 66.7 & 58.3 & NS & NS \\
\hline Early Bird & 750 & 41.7 & 64.6 & 55.6 & NS & NS \\
\hline Carolina Red & 750 & 20.8 & 79.2 & 66.7 & $*$ & $*$ \\
\hline Crimson Gold & 750 & 16.7 & 41.7 & 58.3 & $\cdots$ & NS \\
\hline Durbin & 850 & 16.7 & 45.8 & 79.2 & $*$ & NS \\
\hline Red Gold & 850 & 79.2 & 91.2 & 91.2 & NS & NS \\
\hline Sun Glo & 850 & 83.3 & 91.2 & 91.2 & NS & NS \\
\hline Mean & & 37.7 & 70.1 & 72.4 & $*$ & $*$ \\
\hline
\end{tabular}

***, ${ }^{\mathrm{NS}}$ Significant at $P=0.05$ or 0.01 or nor significant at $P>0.05$, respectively. Data shown arc means of 40 observations. a daily cycle. J. Amer. Soc. Hort. Sci. 104:536540.

Erez, A., G.A. Couvillon, and C.H. Hendershott. 1979b. The effect of cycle length on chilling negation by high temperatures in dormant peach leaf buds. J. Amer. Soc. Hort. Sci. 104:573576.

Erez, A., S. Lavee, and R.M. Samish. 1971. Improved methods for breaking rest in the peach and other deciduous fruit species. J. Amer. Soc. Hort. Sci. 96:519-522.

Samish, R.M. 1954. Dormancy in woody plants. Annu. Rev. Plant Physiol. 5:183-204.

Scalabrelli, G. and G.A. Couvillon. 1986. The effect of temperature and bud type on rest completion and the $\mathrm{GDH}^{\circ} \mathrm{C}$ requirement for budbreak in 'Redhaven' peach. J. Amer. Soc. Hort. Sci. 111:537-540.

Shulman, Y.. G. Nir, and S. Lavee. 1986. Oxidative process in bud dormancy and the uses of hydrogen cyanamide in breaking dormancy. Acta Hort. 179:141-148.

Weinberger, J.H. 1954. Effects of high temperature during the breaking of the rest of Sullivan Elberta peach buds. Proc. Amer. Soc. Hort. Sci. 63:157-162.

Weinberger, J.H. 1967. Some temperature relations in natural breaking of the rest of peach flower buds in the San Joaquin Valley, California. Proc. Amer. Soc. Hort. Sci. 91:84-89. 